\title{
Efektifitas Pemberian Stimulant Better dan Waktu Sadap Terhadap Produksi Lateks Tanaman Karet (Hevea brasiliensis Muell Arg)
}

\section{Effectiveness of Giving Stimulant Better and Tapping Time Against Production of Rubber Latex (Hevea brasiliensis Muell Arg)}

\author{
Engelbertus Huvat $^{1}$, Akhmad Sopian ${ }^{2}$, Tutik Nugrahini ${ }^{2}$, Zainudin ${ }^{2}$
}

${ }^{1}$ Alumni Program Studi Agroteknologi, Fakultas Pertanian, Universitas Widya Gama Mahakam

Jl. KH. Wahid Hasyim, Sempaja, Samarinda, Kalimantan Timur, Indonesia

${ }^{2}$ Tenaga Pendidik Program Studi Agroteknologi, Fakultas Pertanian, Universitas Widya Gama Mahakam Jl. KH. Wahid Hasyim, Sempaja, Samarinda, Kalimantan Timur, Indonesia

Email : engelbertus_huvatt@yahoo.co.id,sopian063@gmail.com,ztjimpolo@gmail.com, tutik.nugrahini@gmail.com

Diterima : 21 Agustus 2018 Disetujui : 12 Oktober 2018

\begin{abstract}
The factors that influence rubber production are planted clones, plant care and tapping techniques. With the right tapping technique, both tapping time, tapping method and mature tapping age, the production potential of a superior clone of rubber plants that has been well maintained can be maintained. The technique of rubber tapping is closely related to the expected level of production, even very determining the age of the tree economy. The research objective was to determine the effect of stimulant better and tapping time on latex production. The method used was a randomized block design with two-factor split plot design. The first factor (main plot) is the time of tapping consists of 3 levels, namely; w1: 05 in the morning, w2: 06 in the morning, w3: 07 in the morning. The second factor (subplot), namely the stimulant dosage better consists of 4 levels, namely; b0: control, b1; $0.5 \mathrm{~g}, b 2 ;: 1 \mathrm{~g}, \mathrm{b3}$; $1.5 \mathrm{~g}$. The results showed that stimulate better treatment had a significant effect on latex volume, wet weight and latex dry weight, but was not significant for latex dryness levels. Tapping time was not significant for latex yield, latex volume, wet weight, latex dry weight and highest dry rubber content at 7am. Stimulant Better treatment has a significant effect on latex volume, wet weight, and latex dry weight, but if given at high doses it will reduce the dry content of rubber. The interaction of treatment when tapping and stimulant is better not significant for latex production. The stimulant application better does not exceed the dose of $0.5 \mathrm{~g} /$ principal. Doses $>0.5 \mathrm{~g} /$ staple will have an impact on the dry tapping field.
\end{abstract}

Keywords: availability, potential, agricultural land, watershed

\section{PENDAHULUAN}

Produktivitas kebun karet ditentukan oleh jenis klon, umur tanaman, tingkat kesesuaian lahan dan sistem eksploitasi yang diterapkan. Penurunan jumlah produksi dapat terjadi salah satunya karena penurunan luas lahan yang terjadi pada tahun tersebut. Usaha peningkatan produksi lateks dewasa ini dilakukan melalui berbagai usaha, antara lain melaksanakan teknis budidaya yang baik seperti menanam klon unggul, pemupukan dengan dosis yang tepat dan teratur, sistem penanaman dan pemeliharaan yang baik dan lain sebagainya (Budiman, 2012).

Faktor-faktor yang mempengaruhi produksi karet adalah klon yang ditanam, perawatan tanaman dan teknik penyadapan. Dengan teknik penyadapan yang tepat, baik waktu sadap, cara penyadapan dan usia matang sadap, maka potensi produksi suatu klon unggul tanaman karet yang telah diipelihara dengan baik dapat terjaga. Teknis penyadapan karet berkaitan erat dengan tingkat produksi yang diharapkan, bahkan sangat menentukan umur ekonomi pohon. Salah satu upaya yang dapat dilakukan untuk mengatasi masalah tersebut adalah dengan meningkatkan produksi karet.Penggunaan stimulan menjadi alternatif untuk meningkatkan produksi pada karet yang produksinya menurun dan mengurangi biaya sadapan yang diakibatkan semakin tinggi biaya tenaga kerja (Sinamo, dkk, 2015).

Bahan perangsang yang biasa dipakai untuk perangsangan dengan cara oles adalah stimulan berbahan aktif ethepon dengan berbagai merek dagang seperti Ethrel, ELS dan Cepha. Bahan aktif ini mengeluarkan gas etilen yang jika diaplikasikan akan meresap ke dalam pembuluh lateks. Di dalam pembuluh lateks gas tersebut menyerap air dari sel-sel yang ada di sekitarnya. 
Penyerapan air ini menyebabkan tekanan turgor naik yang diiringi dengan derasnya aliran lateks. Aplikasi stimulan pada tanaman karet, tidak semua memberikan respons yang diharapkan.Hal ini tergantung pada masing-masing klon karet.

Menurut Heru dan Andoko (2008), sebagai ukuran jika kadar karet kering lateks lebih kecil dari $30 \%$ dengan pemberian stimulan artinya responnya terhadap stimulan kurang berarti,sehingga perlu diketahui jenis-jenis klon yang mempunyai respon yang baik terhadap stimulan berupa zat perangsang tumbuh ethrel yang berbahan aktif ethepon. Frekuensi sadapan merupakan selang waktu penyadapan dengan satuan waktu dalam hari (d), minggu (w), bulan (m) dan tahun (y). Frekuensi penyadapan ini menentukan jumlah produksi pada tanaman karet itu sendiri, terutama pada kadar karet keringnya. Frekuensi penyadapan yang terlalu cepat maka akan mempengaruhi produsi karet keringnya yang rendah, sedangkan dengan menggunakan frekuensi penyadapan yang lebih lamamaka kadar karet keringnya akan lebih tinggi (Damanik, dkk., 2010).

Berdasarkan uraian tersebut diatas, maka dilakukan penelitian mengenai pengaruh perangsang lateks dan waktu penyadapan terhadap produksi lateks tanaman karet. Pemberian stimulant bertujuan untuk meningkatkan produksi lateks.Etephon adalah senyawa 2-chloroethylposhonic acis atau CEPA yang di gunakan sebagai stimulan atau perangsang untuk meningkatan produktivitas hormon etilen endogen pada tanaman karet (Sumarmadji dkk,2005).Etilen merupakan faktor stimulan utama untuk meningkatkan produksi karet alam pada tanaman karet.Enzim yang berperan dalam biosintesis etilen ini salah satunya adalah asam aminosiklopopana-1karboksilat oksidase (ACO). ACO merupakan katalisator dalam perubahan asam aminosiklopopana-1- karboksilat menjadi etilen. Penambahan etephon sebagai bahan stimulasi yang melepaskan etilen pada sistem sadap tertentu, telah umum dilakukan terutama pada perkebunan besar. Aplikasi etephon dimaksudkan untuk menekan biaya eksploitasi dan memperoleh produksi yang tinggi. Namun setiap klon memiliki respons yang berbeda terhadap intensitas eksploitasi.Intensitas eksploitasi mencakup faktor panjang irisan sadap, frekuensi sadap, dan aplikasi stimulasi etephon. Penggunaan etephon yang berlebihan atau intensitas sadapan yang tinggi misalnya $\mathrm{S} / 1$ $\mathrm{d} / 1$ (irisan sadap 1 spiral dan dilakukan setiap hari) seperti yang sering tejadi di perkebunan rakyat, biasanya diikuti oleh tingginya jumlah pohon yang mengalami kekeringan alur sadap (KAS). Sistem eksploitasi yang baik adalah yang memberikan produksi optimal, tidak menekan pertumbuhan tanaman, hemat kulit dan biaya murah serta tidak menimbulkan KAS yangmerupakan gangguan fisiologis sehingga tanaman karet tidak dapat mengalirkan lateks apabila disadap (Siswanto, 2004).

Better 10 PA merupakan stimulant yang berbahan aktif etefon $10 \%$, berbentuk pasta berwarna merah muda yang bekerja secara sistematik masuk kedalam jaringan tanaman menjadi etilen yang mempengaruhi proses fisiologis sehingga dapat meningkatkan produksi lateks pada tanaman karet. Aplikasi Better dilakukan dengan cara pengolesan dengan menggunakan kuas pada bidang sadap dengan interval 5- 7 hari (Anonim, 2018). Frekuensi sadapan merupakan selang waktu penyadapan dengan satuan hari (d), minggu (w), bulan (m) dan tahun (y).Satuan ini tergantung pada system penyadapannya, bila penyadapan dilakukan secara terus menerus setiap hari maka penyadapan tersebut ditandai dengan $\mathrm{d} / 1$. Sedangkan bila dilakukan dengan selang dua hari sekali maka waktunya ditandai dengan $d / 2$, demikian seterusnya (Damanik, dkk., 2010). Frekuensi sadap sangat berpengaruh pada hasil lateks yang telah dipanen atau produksi yang didapatkan pada tanaman karet. Frekuensi penyadapan yang terlalu pendek akan menentukan kualitas lateks yang dihasilkan, karena pada dasarnya pembentukan lateks memerlukan waktu yang cukup lama yaitu 48 jam yang artinya butuh minimal 2 hari untuk lateks benar-benar terbentuk. Jika penyadapan kurang dari 48 jam, maka yang akan didapatkan hanya sebagian kecil dan cenderung banyak air (Sinamo, dkk., 2015).

\section{BAHAN DAN METODE}

Penelitian dilaksanakan pada bulan Agustus Oktober 2018 di kebun karet Dusun Selatan RT 06, Desa Tanah Datar, Kecamatan Muara Badak, Kabupaten Kutai Kartanegara. Metode yang digunakan pada penelitian ini yaitu metode eksperimen menggunakan Rancangan Acak Kelompok dengan percobaan Split Plot Design dengan 3 ulangan. Faktor pertama sebagai main plot yaitu waktu penyadapan terdiri atas 3 taraf yaitu : $\mathrm{w}_{1}$ : pukul 05 pagi, $\mathrm{w}_{2}$ : pukul 06 pagi, $\mathrm{w}_{3}$ : pukul 07 pagi. Faktor kedua sebagai sub-plot yaitu dosis stimulant Better yang terdiri atas 4 taraf yaitu $: b_{0}=$ tanpa stimulant (kontrol), $b_{1}=$ 0,5 g/pokok, $b_{2}=1 \mathrm{~g} /$ pokok, $\mathrm{b}_{3}=1,5 \mathrm{~g} /$ pokok. Parameter yang diamati dalam penelitian ini : volume lateks, berat basah lateks, berat kering karet, dan kadar kering karet. Data dianalisis menggunakan sidik ragam, apabila menunjukkan pengaruh signifikan, maka 
dilakukan uji BNT pada taraf 5\% untuk membandingkan antara perlakuan. Data kadar kering lateks ditentukan menggunakan rumus dari Soepeno (1997) ;

$$
\mathrm{K} 3=\frac{\text { Berat kering lateks }}{\text { Berat basah lateks }} \times 100 \%
$$

\section{HASIL DAN PEMBAHASAN}

Tabel 1. Rata-rata volume, berat basah, berat kering, dan kadar kering lateks dengan percobaan perlakuan waktu sadap

\begin{tabular}{ccccc}
\hline $\begin{array}{c}\text { Perlakuan } \\
\text { Waktu Sadap }\end{array}$ & $\begin{array}{c}\text { Volume Lateks } \\
(\mathrm{ml})\end{array}$ & $\begin{array}{c}\text { Berat Basah } \\
\text { Lateks }(\mathrm{g})\end{array}$ & $\begin{array}{c}\text { Berat Kering } \\
\text { Lateks }(\mathrm{g})\end{array}$ & $\begin{array}{c}\text { Kadar Kering } \\
\text { Karet }(\mathrm{g})\end{array}$ \\
\hline Jam 5 & 436,67 & 405,56 & 221,49 & 58,17 \\
Jam 6 & 438,50 & 379,61 & 227,83 & 57,34 \\
Jam 7 & 520,83 & 481,06 & 290,84 & 58,50
\end{tabular}

Tabel 2. Rata-rata volume, berat basah, berat kering, dan kadar kering lateks dengan percobaan perlakuan stimulat better

\begin{tabular}{ccccc}
\hline $\begin{array}{c}\text { Perlakuan } \\
\text { Stimulant Better }\end{array}$ & $\begin{array}{c}\text { Volume } \\
\text { Lateks }(\mathrm{ml})\end{array}$ & $\begin{array}{c}\text { Berat Basah } \\
\text { Lateks }(\text { gram })\end{array}$ & $\begin{array}{c}\text { Berat Kering } \\
\text { Lateks }(\text { gram })\end{array}$ & $\begin{array}{c}\text { Kadar Kering } \\
\text { Karet }(\text { gram })\end{array}$ \\
\hline Kontrol & $291,33^{\mathrm{a}}$ & $266,27^{\mathrm{a}}$ & $155,94^{\mathrm{a}}$ & 60,78 \\
$0,5 \mathrm{~g} / \mathrm{pkk}$ & $343,89^{\mathrm{ab}}$ & $317,08^{\mathrm{ab}}$ & $203,70^{\mathrm{ab}}$ & 63,71 \\
$1,0 \mathrm{~g} / \mathrm{pkk}$ & $501,67^{\mathrm{b}}$ & $444,08^{\mathrm{b}}$ & $260,98^{\mathrm{b}}$ & 54,09 \\
$1,5 \mathrm{~g} / \mathrm{pkk}$ & $724,44^{\mathrm{c}}$ & $660,88^{\mathrm{c}}$ & $366,26^{\mathrm{c}}$ & 53,43 \\
\hline
\end{tabular}

Tabel 3. Rata-rata volume, berat basah, berat kering, dan kadar kering lateks dengan percobaan perlakuan stimulat better

\begin{tabular}{cccccc}
\hline $\begin{array}{c}\text { Main } \\
\text { Plot }\end{array}$ & $\begin{array}{c}\text { Sub-Plot } \\
\text { Stimulant } \\
\text { Better }\end{array}$ & $\begin{array}{c}\text { Volume } \\
\text { Lateks }(\mathrm{ml})\end{array}$ & $\begin{array}{c}\text { Berat Basah } \\
\text { Lateks }(\mathrm{g})\end{array}$ & $\begin{array}{c}\text { Berat Kering } \\
\text { Lateks }(\mathrm{g})\end{array}$ & $\begin{array}{c}\text { Kadar Kering } \\
\text { Karet }(\mathrm{g})\end{array}$ \\
\hline (w5) & Kontrol & 165,67 & 143,61 & 90,28 & 65,92 \\
Jam 5 & $0,5 \mathrm{~g} / \mathrm{pkk}$ & 294,33 & 280,75 & 154,11 & 58,71 \\
& $1,0 \mathrm{~g} / \mathrm{pkk}$ & 406,67 & 389,63 & 216,21 & 57,80 \\
& $1,5 \mathrm{~g} / \mathrm{pkk}$ & 880,00 & 808,24 & 425,37 & 50,24 \\
& & & & & \\
\hline Jam 6 & Kontrol & 265,67 & 248,87 & 140,98 & 58,66 \\
& $0,5 \mathrm{~g} / \mathrm{pkk}$ & 305,00 & 258,57 & 161,06 & 59,69 \\
& $1,0 \mathrm{~g} / \mathrm{pkk}$ & 553,33 & 434,57 & 279,74 & 54,93 \\
& $1,5 \mathrm{~g} / \mathrm{pkk}$ & 630,00 & 576,46 & 329,55 & 56,09 \\
\hline Jam 7 & & & & & \\
& Kontrol & 442,67 & 406,33 & 236,55 & 57,75 \\
& $0,5 \mathrm{~g} / \mathrm{pkk}$ & 432,33 & 411,93 & 295,95 & 72,74 \\
& $1,0 \mathrm{~g} / \mathrm{pkk}$ & 545,00 & 508,04 & 286,97 & 49,55 \\
& $1,5 \mathrm{~g} / \mathrm{pkk}$ & 663,33 & 597,95 & 343,87 & 53,96 \\
\hline
\end{tabular}

\section{Pengaruh Waktu Sadap}

Hasil sidik ragam menunjukkan bahwa perlakuan waktu sadap tidak signifikan terhadap volume lateks, berat basah, berat kering lateks, dan kadar kering karet. Rata-rata volume, berat basah, berat kering, dan kadar kering lateks dengan percobaan perlakuan waktu sadap disajikan pada Tabel 1.
Waktu sadap tidak signifikan terhadap volume sadap, namun volume lateks yang disadap mengalami peningkatan. Data pengamatan Tabel 1. memperlihatkan bahwa tanaman karet yang disadap pada jam 5 menghasilkan volume lateks 436,67 ml, volume lateks meningkat dengan perlakuan waktu sadap pada jam 6 menjadi $438,50 \mathrm{ml}$ dan pada jam 7 menjadi $520,83 \mathrm{ml}$. 
Berat basah lateks yang disadap pada jam 5 yakni 405,56 $\mathrm{ml}$ lebih tinggi dibandingkan jam 6 yakni $379,61 \mathrm{ml}$, namun pada jam 7 pagi berat basah sadap meingkat menjadi 481,06 ml. Waktu sadap bersifat linier terhadap berat kering lateks, namun bila dilihat dari kadar kering lateks bahwa yang disadap pada jam 6 lebih rendah dibandingakan yang disadap pada jam 5 dan jam 7. Dari data tersebut bahwa tanaman karet yang disadap pada jam 7 meningkat terhadap volume, berat bsah, berat kering dan kadar kering karet. Hal ini sesuai dengan Setiawan dan Andoko (2008), yang menyatakan bahwa bahan aktif etefon yang biasa dipakai untuk stimulan mengeluarkan gas etilen yang jika diaplikasikan akan meresap ke dalam pembuluh lateks. Gas tersebut menyerap air dari sel-sel yang ada di sekitarnya dalam pembuluh lateks. Penyerapan air ini menyebabkan tekanan turgor naik yang diiringi dengan derasnya aliran lateks. Turun naiknya tekanan turgor dipengaruhi oleh waktu (sepanjang hari), yang tentu saja berpengaruh terhadap pengaliran lateks. Tekanan turgor tertinggi adalah pada jam $4.00-8.30$ pagi. Pada saat itu penyadapan layak dilakukan untuk mendapatkan tetesan lateks yang banyak.

\section{Pengaruh Stimulant Better}

Hasil sidik ragam menunjukkan bahwa perlakuan stimulant better significant terhadap volume lateks, berat basah dan berat kering lateks, namun tidak significant terhadap kadar kering lateks. Rata-rata volume, berat basah, berat kering, dan kadar kering lateks dengan percobaan perlakuan stimulat better disajikan pada tabel 2.

Pada dosis $0,5 \mathrm{~g}$ tidak signifikan terhadap kontrol, namun signifikan pada dosis $1 \mathrm{~g}$ dan 1,5 g. Volume lateks yang dihasilkan berbanding lurus dengan berat basah dan berat kering lateks. Produksi tertinggi pada perlakuan 1,5 gram dengan volume lateks $724,44 \mathrm{ml}$, berat basah lateks $660,88 \mathrm{~g}$ dan berat kering lateks $366,26 \mathrm{~g}$. Data pada tabel 2. memperlihatkan adanya respon tanaman karet terhadap pemberian stimulant better. Menurut Heru dan Andoko (2008), bahwa bahan aktif stimulan akan mengeluarkan gas etilen dan meresap ke dalam pembuluh lateks jika diaplikasikan ke tanaman karet, di dalam pembuluh lateks, gas tersebut menyerap air dari sel-sel yang ada di sekitarnya dan menyebabkan tekanan turgor naik.

Hasil analisis kadar kering karet tidak memperlihatkan adanya respon positif dengan pemberian stimulant better. Kadar kering karet tertinggi ditunjukkan pada perlakuan $0,5 \mathrm{~g}$ yakni 63,71 g, sedangkan pada perlakuan $1 \mathrm{~g}$ kadar kering karet 54,09 g dan 1,5 g kadar kering karet $53,43 \mathrm{~g}$, lebih rendah dibandingkan dengan kontrol yakni 60,78 g. Dari hasil tersebut menunjukkan bahwa pemberian stimulant better pada dosis tinggi akan meningkatkan volume, berat basah, dan berat kering lateks, namun berdampak pada menurunnya kadar kering karet.

Menurut Siregar (2012), aplikasi stimulant akan mengurangi kebutuhan air dan menaiknya tekanan turgor sehingga dapat mengakibatkan pengurasan lateks apabila diaplikasikan terhadap areal pertanaman karet yang disadap dengan frekuensi tinggi seperti satu kali dua hari. Lateks yang dieksploitasi secara berlebihan akan memicu proses transpirasi lebih cepat sehingga tanaman menjadi kerdil dan mudah terserang hama penyakit. Hal ini sesuai dengan Lakitan (2007), bahwa jika proses transpirasi ini cukup besar dan penyerapan air tidak dapat mengimbanginya, maka tanaman tersebut akan mengalami kelayuan sementara (transcient wilting), sedangkan tanaman akan mengalami kelayuan tetap, apabila keadaan air dalam tanah telah mencapai permanent wilting percentage. Tanaman dalam keadaan ini sudah sulit untuk berproduksi karena sebagian besar sel-selnya telah mengalami plasmolisis. Menurut Siregar (2012) penggunaan stimulant yang berlebihan akan menurunkan kadar karet kering dan dapat menyebabkan penyakit bidang sadap alur.

\section{Interaksi Waktu Sadap dan Stimulant Better}

Hasil sidik ragam menunjukkan bahwa interaksi perlakuan waktu sadap dan stimulant better tidak significant terhadap volume lateks, berat basah, berat kering lateks, dan kadar kering karet. Rata-rata volume, berat basah, berat kering, dan kadar kering karet dengan interaksi perlakuan disajikan pada tabel 3 .

Data interaksi perlakuan tertinggi pada perlakuan waktu sadap jam 5 dengan dosis stimulant $1,5 \mathrm{~g} / \mathrm{pkk}$ dengan volume lateks $880,00 \mathrm{ml}$, berat basah lateks tertinggi $808,24 \mathrm{~g}$, dan berat kering lateks tertinggi 808,24 g. Namun kadar kering karet tertinggi pada jam 7 dengan $0,5 \mathrm{~g} / \mathrm{pkk}$ yakni $72,74 \mathrm{~g}$. Dari data tersebut menjelaskan bahwa perlakuan waktu sadap jam 7 dengan stimulant better pada dosis $0,5 \mathrm{~g} / \mathrm{pkk}$ tidak terjadi pengurasan lateks dan tidak berakibat penyakit bidang sadap alur. Tidak signifikan interaksi diduga kedua faktor tidak bekerja secara simultant yakni pemberian stimulant better tidak tergantung waktu sadap. Waktu sadap berhubungan dengan tekanan turgor, namun sejalan dengan waktu dan intensitas sinar matahari semakin tinggi, maka akan menyebabkan tekanan turgor semakin menurun, sehingga pengaliran lateks semakin 
sedikit. Fenomena ini akan semakin nyata bila diamati pengaliran lateks pada menit pertama setelah penyadapan di pagi hari. Pada menit berikutnya, jarak waktu antara tetesan yang satu dengan tetesan yang lain akan semakin lambat dan berkombinasi dengan meningkatnya suhu lateks cenderung membeku di alur sadap (Siregar, 2012).

\section{KESIMPULAN}

1. Waktu sadap tidak signifikan terhadap hasil lateks, namun volume lateks, berat basah, berat kering lateks dan kadar kering karet tertinggi pada sadap jam 7 pagi.

2. Perlakuan stimulant Better berpengaruh signifikan terhadap volume lateks, berat basah, dan berat kering lateks, namun jika diberikan pada dosis tinggi akan menurukan kadar kering karet. Interaksi perlakuan waktu penyadapan dan stimulant better tidak signifikan terhadap produksi lateks. Aplikasi stimulant better sebaiknnya tidak melebihi dosis 0,5 g/pokok. Dosis > 0,5 $\mathrm{g} /$ pokok akan berdampak pada keringnya bidang sadap.

\section{UCAPAN TERIMA KASIH}

Ucapan terimakasih disampaikan kepada Program Studi Agroteknologi Fakultas Pertanian Universitas Widya Gama Mahakam yang telah memfasiltasi terselenggaranya penelitian ini. Ucapan terima kasih juga disampaikan kepada Pemerintah Kabupaten Kutai Kartanegara melalui UPT Perkebunan di Kecamatan Muara Badak yang telah memberikan ijin lokasi serta objek penelitian kepada penulis untuk melakukan penelitian.

\section{DAFTAR PUSTAKA}

Abdullah, R. 2009. Sejarah dan Prospek Pengembangan Karet. Retrieved Maret 10, 2012, from Balitgetas: http://balitgetas.wordpress.com.

Anonim,2008. Panduan Lengkap Karet. Penebar Swadaya, Jakarta.

Anonim, 2018. Zat Pengatur Tumbuh Better. PT. Petrokimia Kayaku (Petrokimia Gresik Group). Gresik, Jawa Timur.
Budiman, H. 2012. Budidaya Karet Unggul. Pustaka Baru Press, Yogyakarta.

Damanik, S.,Syakir, M.Tasma,M. Siswanto. 2010. Budidaya dan Pasca Panen Karet. Pusat Penelitian dan Pengembangan Perkebunan. Bogor.

Didit, H. dan Agus, A. 2010. Petunjuk Lengkap Budidaya Karet. Agromedia Pustaka, Jakarta.

Hanafiah, K. A. 2010.Rancangan Percobaan: Teori dan Aplikasi. Raja Grafindo Persada, Jakarta.

Heddy, S. 1996. Hormon Tumbuhan. Raja Grafindo Persada, Jakarta.

Heru, D.S dan A. Andoko, 2008. Petunjuk Lengkap Budidaya Karet. Agromedia Pustaka, Jakarta.

Lakitan, B. 2007.Dasar-Dasar Fisiologi Tumbuhan. Raja Grafindo Persada, Jakarta.

Setiawan, D.H dan A. Andoko. 2008. Petunjuk Lengkap Budidaya Karet Edisi Revisi. Agromedia Pustaka, Jakarta.

Sinamo, H., Charloq., Rosmayati.,dan Radite, 2015. Respon Produksi Lateks Dalam Berbagai Waktu Aplikasi Pada Beberapa Klon Tanaman Karet Terhadap Pemberian Berbagai Sumber Hormon Etilen. Program Studi Agroekoteknologi Fakultas Pertanian Universitas Sumatra Utara.

Siregar, T. H. 2012. Budi Daya dan Teknologi Karet. Penebar Swadaya, Jakarta.

Siswanto,2004.Kekeringan Alur Sadap Tanaman Karet: Perubahan Karakter Fisiologis, Identifikasi Penanda Protein dan Cara Pengendaliannya. Makalah Rapat Keja Evaluasi Hasil Penelitan Unggulan Badan Litbang Pertanian, Bogor. 